流れの可視化 Vol.9 No.34 (1989年 7月)

14 「クリーンルーム内に存在する下降流と火災上开気流の流れ場の可視化」

$\begin{array}{ll}\text { 東京理科大学火災研 } & \text { 須川修身 } \\ \text { 東京理科大学大学院 } & \text { 岡 泰凅 } \\ \text { 東京理科大学大学院 } & \text { 上野浩志 } \\ \text { 哌島建設設計部 } & \text { 原 良夫 }\end{array}$

Visualization of a counter-flow field in a clean room Osami SUGAWA* Yasushi OKA** Hiroshi UENO** and Yoshio.hARA***

Experimental study was conducted in the flow field of a clean room subject to a clean room fire. The counter-flow which was caused by downard flow and upward current from a model fire source was visualized using two kinds of smoke. A point source or a line fire source was adopted as a model fire source. respectively.

While the buoyancy force depends on the heat release rate, hot current which included smoke from the model fire source rose against down flow and reached at least $2 \pi$ height in this experiment. This updraft current upon contacting the down flow was observed to form an umbrella shape. Most of the air. floor and walls in the clean room were contaminated with combustion particles within a few seconds.

1.はU゙ぬに

クリーンルームは温湿度を高度に調整し 人工的に作り出された空間でるととむに、 工業・生物・医療等各分野汇おいて重要な 施設である。そこで、クリーンルーム内の 気流性状の把握お よび清浄度確保のため可 䘽化に上了報告が数多くなされているい。 火災分野においてむ火災室からの熱気流や 堙の喷出状況”、廊下内の嫱流動性状の把 握3.4さらに火炎の形扰测定 ${ }^{5}$ など可視化 加用いられている。
初期火災火源から発生す万熱や煙在伴。 た上暑気流山非常に弱い流れであるた内既 存の流れに原めて影望在受け忽い。このた 为熱気流か上暑途中て停滞したり、希积さ れたり、流れの方向を大きく变化させられ たりする。クリーンルーム内て火災が発生 すると火災熱気流が持つ乱れと区画内に存 在する流れとの相互作用により生ずる乱れ によって区画内の流れはより複雑となるた め和早期に感知できない可能性があるだけ でく、清浄度にも多大な影腤を及ほす。

* Center for Fire Science and Technology. Science University of Tokyo

* Science University of Tokyo, 2641 Yamasaki. Noda-shi. Chiba 278

***TOBISHIMA CORPORATION Ltd.. 2 Sanban-cho. Chisoda-kll. Tokyo 102 
そこて、、層流クリーンルーム内で発生す る模擬火災を想定し、火源上に形成される 熱気流と天井面からの下降流とによって作 り出される流れ場の可視化を行ったのて報 告する。

\section{2. 実験方法および可視化方法}

\section{1 燃焼区画}

実験に使用した実大層流クリーンルーム の概要を図1に示す。

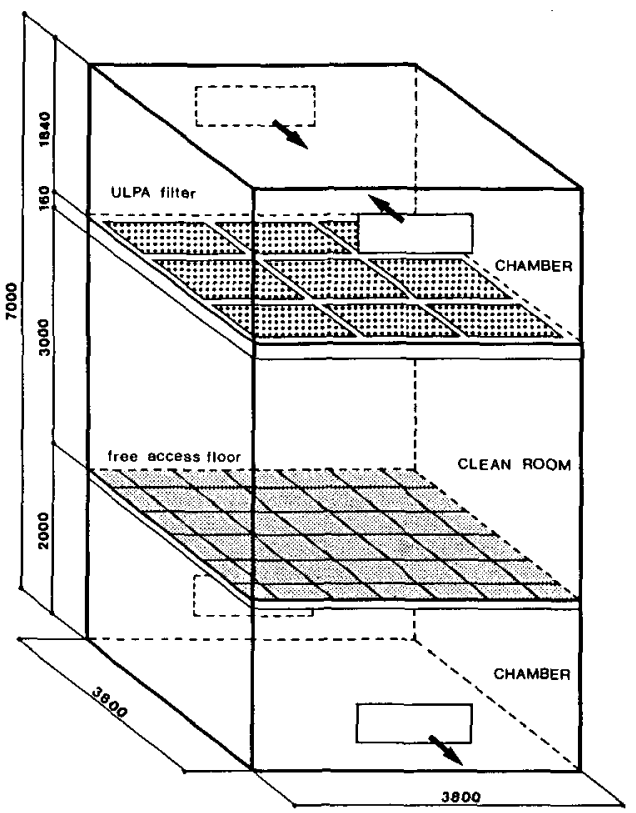

Fig.1 Clean room

天井上部およひ床下にはそれそれ空調流の 吹き出し、吸い込み用のチ+ンハーが設箅 されている。吹き出し、吸い込み用千+ン バーの大きさは両者とむ $3.8 \mathrm{~m}(\mathrm{~W}) \times 3.8 \mathrm{~m}(\mathrm{~L})$ ห2.0m(H)である。吹き出し用チャンバーと クリーンルーム浪、厚さ160 mm U UPA Fi l terによって甘切られており、床面は開口 率 40\%のフリーアクセスフロアーとなって いる。天井面加ら下降気流の吹き出し速 度は $0.25,0.45 \mathrm{~m} / \sec の 2$ 段階とした。 2.2 モデル火災火源
模擬火災火源には中火源 $(\phi 100 \mathrm{~mm})$ と線 状火源（Icm $\times 2$ m) 使用した。発熱速度は それぞれ約 $1.6 \mathrm{~kW} ， 13 \mathrm{~kW}$ あった。

2.3 可視化方法

可視化は煙発生㯏置てからの煙および漏 洩試呀用発煙片を用いた。喓の吹き出し， ズルフリーアクセスフロアー上 $2100 \mathrm{~mm}$ 設置した。可視化方法を図 2 に、使用した 器具を表 1 に示す。

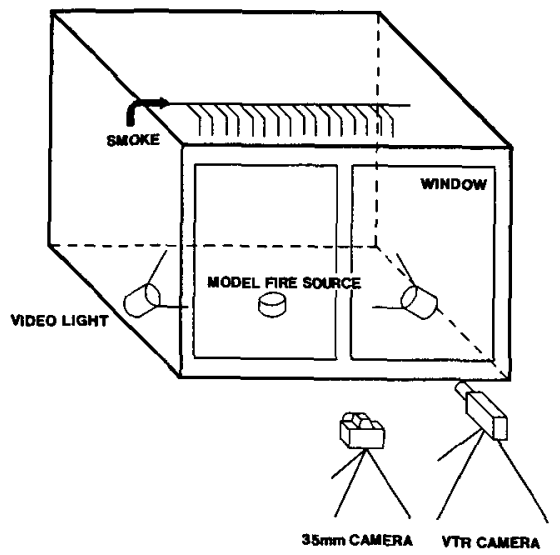

fig. 2 Schematic view of flow visualization

\begin{tabular}{ll}
\multicolumn{1}{c}{ Table. } & Camera condition \\
\hline Film & ISO 1600 \\
Namera color fi lm & Minolta $\alpha-7000$ \\
Shutter speed & auto \\
lriss & auto \\
Lens & $35-105 m m+3.5-4.5$ \\
\hline
\end{tabular}

3. 結果

3.1 線状火源の場合

線状火源上に形成されるブリュームの着 火直後の樣子在写真 1 示す。下降気流速 度注 $25 \mathrm{~cm} / \mathrm{sec}$ でる。熱気流法周りの空気 卷き込みながら上昇儿。熱気流は着火15 秒後すでにフリアクセスフロアー上 $2 \mathrm{~m}$ 以上に到達している事が煙の動きから確認 され当。 
(a)

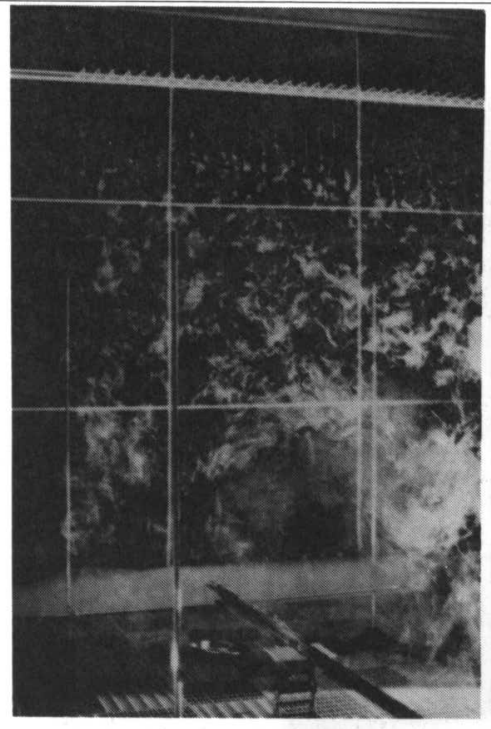

(c)

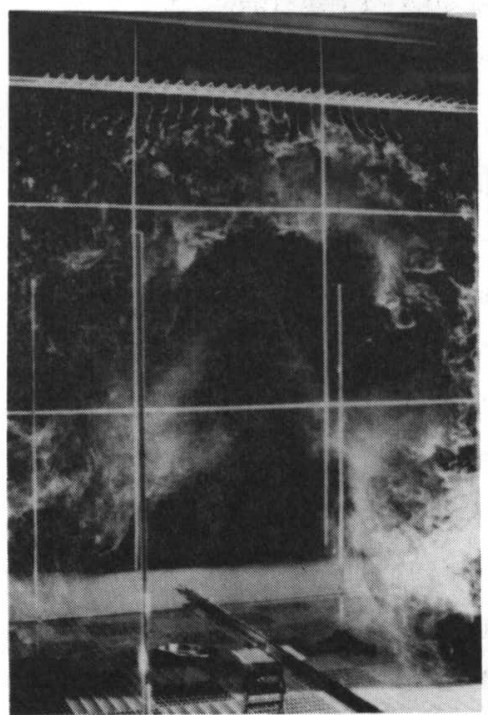

(b)

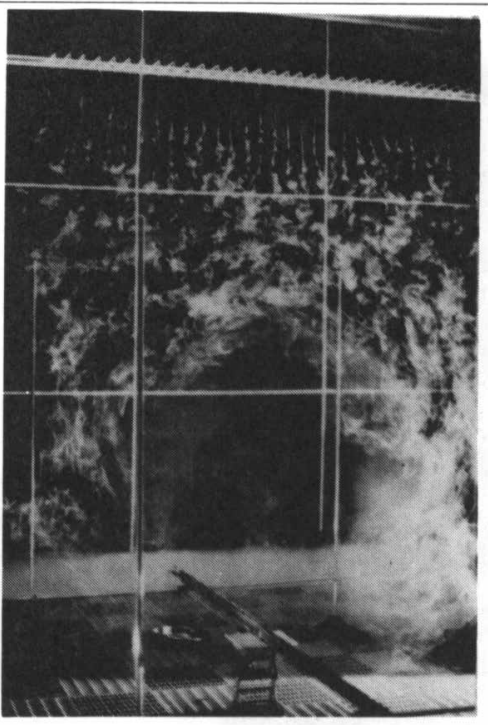

(d)

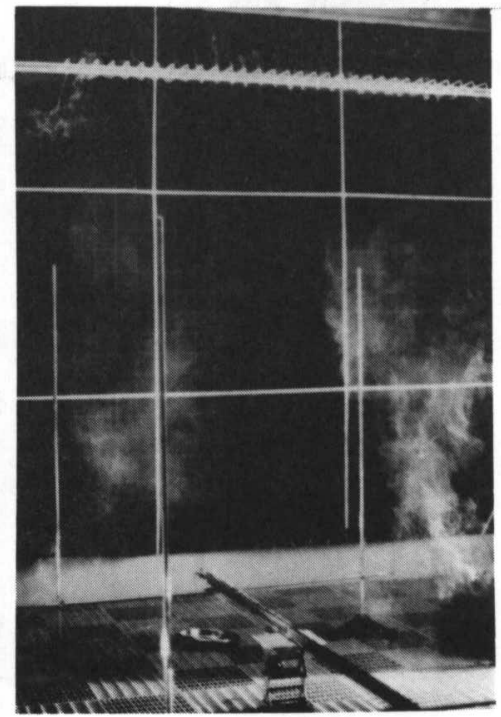

Photo.1 Smoke visualization of a fire plume using a line model fire source after. a: 1 sec, b:5 sec, c:10 sec, d:15 sec

\section{2 円形火源の場合}

円形火源上に形成したずリュームの样子 を写真 2 に示す。下降気流速度は $45 \mathrm{~cm} / \mathrm{sec}$ である。また、漏洩試験用発煙片によるフ リュームの可視化例を写真 3 に示す。下降 気流速度は $40 \mathrm{~cm} / \mathrm{sec}$ ある。

4.まとめ
火災熱気流を可視化する場合、上手に上 昇熱気流に煙釆せてやらないとまったく 異なった現象を可視化してしまう恐れがあ るので十分に注意を払う必要がある。

火源加ら発生した熱気流は下降流に対抗 しつつ火源軸に沿って左右に摇れながら上 昇する。熱気流の到達高さは火源の発熱量 に依存するか、火源上少なくとも $2 \mathrm{~m}$ まで 


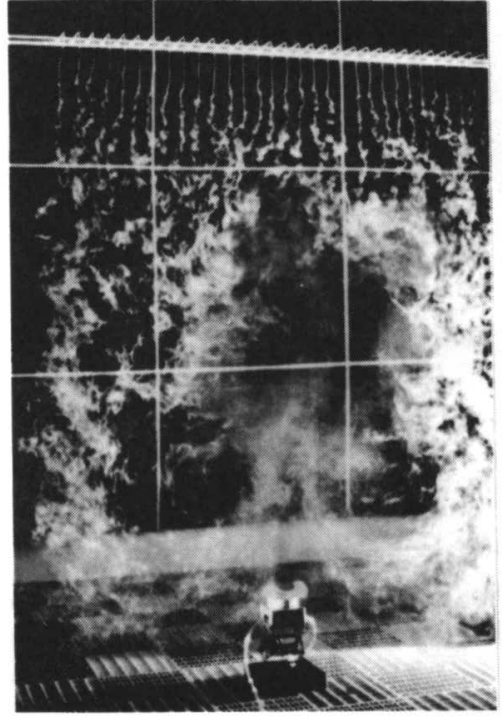

Photo. 2 Visualization of fire plume with down flow of $45 \mathrm{~cm} / \mathrm{sec}$

上昇した。火災熱気流沖火源上に幽を広汁 たような形状を見せ、既に区画内に存在し た下降流によって床下に運ばれるが火災気 流かむたらす乱れのために摭散・混合現象 が瀕著になる結果、区画内のかなりの空間 およじ床や壁を数秒のうちに污染する。

\section{5. 参考文献}

1) 例え

「層流型クリーンルーム内気流のレーザ

ーライトシートによる可視化」

流れの可視化. $101.5, N 0.18$,

p229 234, 1985

2)Quintiere, J.G., McCaffrey. B.J..

and Rinkinen, $W$.

"Visualization of Room Fire Induced Smoke Movement and Flow in a Corridor". Fire and Materials, Vol 2, No.1, p18 25, 1978

3) Handa T.. and Sugawa 0 .

"Characterization of Flow Behavior of Hot Fire Products in a concrete

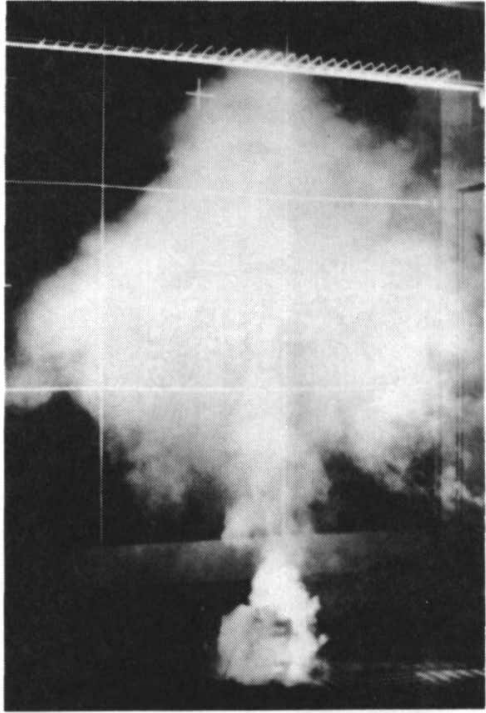

Photo.3 Visualozation of fire plume with down flow of $40 \mathrm{~cm} / \mathrm{sec}$

Full Scale corridor".

Fire Science and Technology. Iol.1.

No.1. p $45 \sim 70,1981$

4 ) 江守一郎、斉藤孝三

「ビル火災時に火災廊下で生じる気流伝 播の模型実験と相似則」

日本火災学会論文集、Vol.29. N o. 2.

p $41 \sim 49.1979$

5 )川越邦雄、内山久雄、長谷見雄二、

水野智之. 「火炎の幾何学的形状測定」 災害の研究, Vol.12, p9 1 97, 1981,

日本損害保険協会

6) Sugawa 0.. Oka Y., and Hotta H.

"Fire Induced flow in a Clean Room with Downward Vertical Laminar Flow" 9 th Joint Panel Meeting of the UJNR Panel on Fire Research and Safety, NBSIR $88-3753, p 357 \sim 366,1988$

7 ) 瀨田恵之、菅原仁他

「たばこの煙を用いたクリーンルーム内の 気流の可視化実験例」, 流れの可視化、 Suppl. Vol.7, p93 96, 1987 